\title{
EdITORIALS
}

\section{Note from the editors: The 2012 impact factors}

Eurosurveillance editorial team (eurosurveillance@ecdc.europa.eu) ${ }^{1}$

1. European Centre for Disease Prevention and Control (ECDC), Stockholm, Sweden

Citation style for this article:

Eurosurveillance editorial team. Note from the editors: The 2012 impact factors . Euro Surveill. 2013;18(26):pii=20515. Available online: http://www. Eurosurveillance editorial team. Note from the editors: The
eurosurveillance.org/ViewArticle.aspx?Articleld $=20515$

Article submitted on 27 June 2013 / published on 27 June 2013

Public health experts, epidemiologists and other scientists are used to handle numbers. They use numeric data to compare and evaluate trends, and often put forward recommendations and act based on their analyses. Publishers and editors do the same for their journals. The best known metric to compare scientific journals is the journal impact factor. It is computed based on a formula developed by Eugene Garfield and used by Thomson Reuters [1], who have recently released their 2012 Journal Citation Reports and journal impact factors [2].

Due to its known limitations, a number of renowned editors and publishers of scholarly journals suggested in The San Francisco Declaration on Research Assessment (DORA) in late 2012, that the much debated impact factor should not be marketed without putting it into context with other metrics [3]. Nonetheless, it is still used widely to appraise journals.

The first ever impact factor for Eurosurveillance for the year 2011 was high: 6.15. Many assumed that this was mainly a result of the unique role of Eurosurveillance in 2009 with regard to the rapid publishing of peerreviewed papers on the influenza $A\left(\mathrm{H}_{1} \mathrm{~N}_{1}\right) 2009$ pandemic. However, our second impact factor of 5.49 is still considerable. We also retain the sixth position among the 69 journals in the category Infectious Diseases and with that remain in the first quartile [2]. Our second impact factor confirms that we are well established among the journals in our field. The 2012 figures for the increasingly popular Scopus-based SCImago Journal Rank (SJR) are not yet available for comparison, but in 2011 we held place 60 amongst 1,563 journals in the field of Medicine (miscellaneous) [4].

Of course we would like to use this occasion to thank our readers and contributors once again for their engagement and confidence in our journal and to provide additional information to allow our audience to see our impact factor in a broader context. In particular we want to highlight the top 10 Eurosurveillance articles from 2010 and 2011 receiving the highest number of citations in 2012 according to Scopus (Table) [5]. The listed articles demonstrate that a variety of subjects has contributed to the 2012 impact factor.
There were other indicators of the impact and increasing reputation of Eurosurveillance in the past year, such as the a number of submissions to our journal on influenza $A\left(\mathrm{H}_{7} \mathrm{~N} 9\right)$ from China and other countries outside Europe, as well as a considerable increase in submissions overall.

In particular, we note a new trend in the speed with which articles on the emergence of the influenza $\mathrm{A}\left(\mathrm{H}_{7} \mathrm{~N} 9\right)$ virus and on the Middle East Respiratory Syndrome Coronavirus (MERS-CoV) were published in a number of scientific journals, including such prestigious journals as the British Medical Journal (BMJ), the Lancet and the New England Journal of Medicine (NEJM), while during the 2009 influenza pandemic, Eurosurveillance was still quite unique in communicating findings within days through our 'Rapid Communications'. We feel encouraged by the thought that our journal might have led the way to faster sharing of information in times of emerging pathogens or outbreaks with an impact on public health.

As in previous years, our articles featured regularly in traditional and social media. Our Twitter account has now more than 2,000 followers, many of whom are very active on social media. In 2012, ProMED, the Internetbased platform dedicated to rapid global dissemination of information on outbreaks of infectious diseases and acute exposures to toxins that affect human health, posted more than 50 Eurosurveillance articles [6].

Our editorial policy and way of working is attractive to other journals. In the past two years, we were approached on several occasions by editors in the process of establishing regional journals outside Europe with a similar scope to ours, who were following the Eurosurveillance model. This is a satisfying acknowledgement of our work. We are happy to collaborate and share our experiences, to further the communication, in a local/regional context, of public health events that may not be not be in the scope own journal as they may lie outside our focus on events of European relevance.

These positive signs encourage us to remain true to our editorial policy in which we strive to be of practical use for our readers and to have an impact, sometimes immediate, on public health action. 
Köck R, Becker K, Cookson B, van Gemert-Pijnen JE, Harbarth S, Kluytmans J, Mielke M, Peters G, Skov RL, Struelens MJ, Tacconelli E, Navarro Torné A, Witte W, Friedrich AW. Methicillin-resistant Staphylococcus aureus (MRSA): burden of disease and control challenges in Europe. Euro Surveill. 2010;15(41):pii=19688. Available from: http://www.eurosurveillance.org/ViewArticle.aspx?Articleld=19688

La Ruche G, Souarès Y, Armengaud A, Peloux-Petiot F, Delaunay P, Desprès P, Lenglet A, Jourdain F, LeparcGoffart I, Charlet F, Ollier L, Mantey K, Mollet T, Fournier JP, Torrents R, Leitmeyer K, Hilairet P, Zeller H, Van Bortel W, Dejour-Salamanca D, Grandadam M, Gastellu-Etchegorry M. First two autochthonous dengue virus infections in metropolitan France, September 2010. Euro Surveill. 2010;15(39):pii=19676. Available from: http:// www.eurosurveillance.org/ViewArticle.aspx?Articleld $=19676$

Grundmann H, Livermore DM, Giske CG, Canton R, Rossolini GM, Campos J, Vatopoulos A, Gniadkowski M, Toth A, Pfeifer Y, Jarlier V, Carmeli Y, the CNSE Working Group. Carbapenem-non-susceptible Enterobacteriaceae in Europe: conclusions from a meeting of national experts. Euro Surveill. 2010;15(46):pii=19711. Available from: http://www.eurosurveillance.org/ViewArticle.aspx?Articleld=19711

Scheutz F, Møller Nielsen E, Frimodt-Møller J, Boisen N, Morabito S, Tozzoli R, Nataro JP, Caprioli A.

Characteristics of the enteroaggregative Shiga toxin/verotoxin-producing Escherichia coli $\mathrm{O}_{104} \mathrm{H}_{4} \mathrm{Strain}$ causing the outbreak of haemolytic uraemic syndrome in Germany, May to June 2011. Euro Surveill. 2011;16(24):pii=19889. Available from: http://www.eurosurveillance.org/ViewArticle.aspx?Articleld=19889

Ready PD. Leishmaniasis emergence in Europe. Euro Surveill. 2010;15(10):pii=19505. Available from: http:// www.eurosurveillance.org/ViewArticle.aspx?Articleld $=19505$

Ikonen N, Strengell M, Kinnunen L, Österlund P, Pirhonen J, Broman M, Davidkin I, Ziegler T, Julkunen I. High

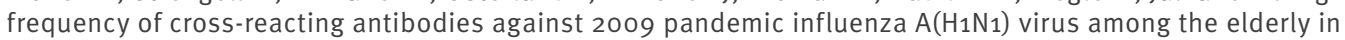
Finland. Euro Surveill. 2010;15(5):pii=19478. Available from: http://www.eurosurveillance.org/ViewArticle. aspx?Articleld $=19478$

Unemo M, Golparian D, Syversen G, Vestrheim DF, Moi H. Two cases of verified clinical failures using internationally recommended first-line cefixime for gonorrhoea treatment, Norway, 2010. Euro Surveill. 2010;15(47):pii=19721. Available from: http://www.eurosurveillance.org/ViewArticle.aspx?Articleld=19721

Ison CA, Hussey J, Sankar KN, Evans J, Alexander S. Gonorrhoea treatment failures to cefixime and azithromycin in England, 2010. Euro Surveill. 2011;16(14):pii=19833. Available from: http://www.eurosurveillance.org/ ViewArticle.aspx?Articleld=19833

Hardelid P, Fleming DM, McMenamin J, Andrews N, Robertson C, SebastianPillai P, Ellis J, Carman W, Wreghitt T, Watson JM, Pebody RG. Effectiveness of pandemic and seasonal influenza vaccine in preventing pandemic influenza $A\left(\mathrm{H}_{1} \mathrm{~N}_{1}\right) 2009$ infection in England and Scotland 2009-2010. Euro Surveill. 2011;16(2):pii=19763. Available from: http://www.eurosurveillance.org/ViewArticle.aspx?Articleld=19763

Kilander A, Rykkvin R, Dudman SG, Hungnes O. Observed association between the HA1 mutation D222G in the 2009 pandemic influenza $A\left(\mathrm{H}_{1} \mathrm{~N}_{1}\right)$ virus and severe clinical outcome, Norway 2009-2010. Euro Surveill. 2010;15(9):pii=19498. Available from: http://www.eurosurveillance.org/ViewArticle.aspx?Articleld=19498

42 times

37 times

36 times

35 times

31 times

29 times

28 times

27 times

24 times

23 times

Source: [5].

\section{References}

1. Garfield E. The history and meaning of the journal impact factor. JAMA. 2006;295(1):90-3.

2. Thomson Reuters. Journal Citation Reports. Journal summary list. New York, NY: Thomson Reuters. [Accessed 26 Jun 2013]. Available from: http://admin-apps.webofknowledge.com/JCR/ JCR

3. San Francisco Declaration on Research Assessment (DORA): San Francisco, California [accessed 27 June 2013] Avaliable from: http://am.ascb.org/dora/

4. SCImago. SJR - journal rank. [Accessed 26 Jun 2013]. Available from: http://www.scimagojr.com/journalrank.php?category $=2701 \&$ area $=0$ \&year $=2011 \&$ country $=\&$ order $=\operatorname{sjr} \& \mathrm{~min}=0 \& \mathrm{~m}$ in_type $=$ cd\&page $=1$

5. Scopus. Philadelphia: Elsevier. [Accessed 27 Jun 2013]. Available from: http://www.scopus.com/home.url

6. ProMED-mail. Brookline, MA: International Society For Infectious Diseases. [Accessed 26 Jun 2013]Available from: http://www.promedmail.org/?p=2400:1200:424240 